\title{
Customer satisfaction basis for sustainable traditional authentic ethnic restaurants in Ilocos Sur
}

Sanchez, Remedios V. $₫$

Ilocos Polytechnic State College, Philippines (Rjoyce1104@gmail.com)

Apritado, Jennie Margaret M.

Lyceum of the Philippines University Batangas, Philippines (jmapritado@lpubatangas.edu.ph)

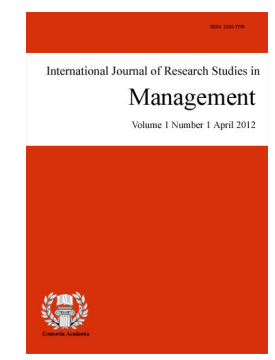

ISSN: $2243-7770$ Online ISSN: 2243-7789

OPEN ACCESS

\section{Abstract}

The primary purpose of the study was to determine customer satisfaction as a basis for the sustainability of authenticity and ethnicity of the restaurants in Ilocos Sur. Specifically, it presented the profile of the respondents in terms of sex, age, highest educational attainment, personal monthly income, it determine the quality of service in terms of tangible, reliability, responsiveness, assurance, empathy, food authenticity, ethnicity, food quality, service quality, physical environment, as the basis for customers' satisfaction. Descriptive research was used with 395 as respondents composed of foreign and local customers who visited and dine in different traditional ethnic authentic restaurants in Ilocos Sur. The survey instrument consisted of items in profiling of the respondents and utilized a frequency and percentage distribution, weighted mean, t-test, and ANOVA as statistical tools. As shown from the results on the comparison of assessment in terms of service quality and assessment of customer satisfaction both verbally agree. This means that respondents are satisfied in restaurants in terms of tangibility, reliability, responsiveness, assurance, empathy, food authenticity, food quality, service quality, and physical environment. The researcher concludes that on comparison of responses, there is a significant difference in assessing service quality and customer satisfaction when group according to the profile variables as shown results has significant difference occurred and they differ in preference in assessing the service quality and customer satisfaction. An Action Plan was proposed to continuously improve the quality of service, food authenticity and to attract more customers and exceed satisfaction after the findings of this study.

Keywords: authentic, customer satisfaction, ethnic restaurants, quality of service 


\section{Customer satisfaction basis for sustainable traditional authentic ethnic restaurants in Ilocos Sur}

\section{Introduction}

As years passed by, traditional authentic restaurant enhances to establish its name to market and make it popular in the hospitality industry most especially to Ilocos Sur for they well known for its authentic dishes that one can say "no" to experience sumptuous dishes, natural wonder, cultures, and amazing restaurants experienced even though food industry is affected to the situation we are facing now the viral COVID-19 dilemma.

Every region wanted to establish its famous cuisine with a specific set of cooking traditions using ingredients, with a unique combination of flavors that develops over time to make customers meet satisfaction in terms of quality service and food authenticity that might like to explore by individuals. Other countries expanded these sole foods through trade using producing; people can survive economically by way of food not only for consumption. Authentic restaurants produce traditional cultures like traditional cooking techniques to value its cultural heritage and let tourists experience the Ilocano culture of food and dining experienced. Ilocos Sur is one of the places here in the Philippines that developed as a center of the hub through food tourism destination aside from those nature's wonders that Ilocos Sur offers to local and foreign travelers.

Aside from politics, Filipinos' favorite subject is food. Filipinos are known for their love of food. We eat with gusto, whether in high-end restaurants or our own homes. So, do we eat to live or live to eat? I suppose both because what is life without those delectable typical Ilocano delicacies? We enjoy fine Filipino cuisine whenever we have the opportunity and whenever we are in the mood. Every one of us wants to eat and likes to enjoy the food we dine in the different restaurants because we want to satisfy not only our taste buds but the service that they do for us- customers.

The effect of service quality which is measured by the SERVQUAL dimensions, price, meal pace, and authenticity, on customer satisfaction, was studied by Ngoc and Uyen (2015) carried out a study to know the essential factors of food service quality. In this study, they identified two categories of dimensions connected to products and customers. The product category included product character, culinary arts hygiene, and safety. The customer category is comprised of environment atmosphere, marketing, promotion, and service quality.

Tandon et al. (2017) describe customer satisfaction as "one of the most studied constructs in marketing literature," and it plays a role in the market-based economy due to its ability to attract existing and future customers. Customer loyalty is critical to the success of every business enterprise. When a company is about to start, customers often come "first" followed by benefit. Companies that succeed in fully satisfying their customers will remain at the top of the industry. Customers in general are people who purchase products and services from a market or business that suit their needs and desires. Customers buy goods to achieve their financial goals. As a result, businesses must align their prices with the product's quality to retain customers (Khadka \& Maharjan, 2017).

The restaurant's business quality can be assessed based on the inherent characteristics of the products being offered such as taste, appearance, portions, texture, and others. However, having an excellent product does not always guarantee customer satisfaction. The factor of being able to give options that provide convenience to the customer also influences the concept of "quality service" which translates to customer satisfaction.

When eating out, the term "authentic" is often used in two separate contexts. Customers both domestic and international travelers want to visit a particular location not only for the beauty of the location but also to sample its cuisine. Tasting the local cuisine of one's location is a wonderful way to experience its history. Food is vital to everyone's well-being, and today it is considered a luxury. Many visitors nowadays are delighted and yearn for

98 Consortia Academia Publishing (A Partner of Tourism Educators and Movers of the Philippines) 
an adventure, for they want to taste or try the local specialties; as a result, tourists both domestic and foreign often choose authentic local cuisine to round out their experience. Restaurants allow visitors to sample local foods and beverages, and they are one way of promoting traditional cuisine. The researcher conducted this study focusing on an in-depth assessment of customer satisfaction as the basis for sustainable innovations among traditional ethnic authentic restaurants in Ilocos Sur, based on the foregoing context on customer satisfaction, service quality, and authentic delicacies.

\subsection{Objectives of the study}

This study generally assessed the customer satisfaction basis for sustainable traditional authentic ethnic restaurants in Ilocos Sur. Specifically, it aims to: (1) Present the demographic profile of the respondents in terms of sex, age, highest educational, personal monthly income; (2) determine service quality in terms of tangible, reliability, responsiveness, Assurance, Empathy; (3) To determine customers' satisfaction in terms of food authenticity, food quality, service quality, physical environment to the traditional authentic restaurants in Ilocos Sur; (4) Test the significant difference on the assessment of service quality and customer satisfaction when grouped according to the profile variables; (5) propose an action plan for sustainable service innovations among traditional ethnic authentic restaurants in Ilocos Sur.

\section{Methods}

\subsection{Research Design}

This study utilized the descriptive design and the quantitative research approach. This design is suitable for this study since it focuses primarily on describing the customer's level of satisfaction for sustainable traditional authentic restaurants in Ilocos Sur. A descriptive analysis focuses on describing the essence of a population segment rather than on "why" a specific phenomenon occurs. In other situations, the study's subject is "identified" without an explanation of "why" it occurs.

\subsection{Participants}

The respondents of the study were briefly selected, and 395 foreign and local customers visited, and dine in different traditional ethnic authentic restaurants in Ilocos Sur. The researcher used purposive sampling wherein the respondents were assumed to be knowledgeable on the topic. Respondents are both foreign and local customers, who visited the different traditional ethnic authentic restaurants in Ilocos Sur. Respondents should be a customer of the traditional ethnic authentic restaurants that can be read, write, and talk in different dialect or language.

\subsection{Instrument}

The researcher adopted the questionnaire from the study of Zhang et al, (2019) entitle Authenticity, Quality, and Loyalty Local Food and Sustainable Tourism Experience, and the study of Khin (2020), entitled Examining the Important Factors of Service Quality Contributing to Customer Satisfaction within Foreign Franchise Restaurant Industry in Yangon Myanmar since the questionnaire was adopted, this was already tested and reliable. Part I presents the demographic profile of the respondents in terms of sex, age, highest educational qualification, and personal monthly income; Part II assesses the service quality in terms of tangible, reliability, responsiveness, Assurance, and Empathy; and Part III determines the factors affecting satisfaction on customers in terms of food authenticity, food quality, service quality, physical environment the traditional authentic restaurants in Ilocos Sur. 
Sanchez, R. V., \& Apritado, J. M. M.

\subsection{Data Gathering Procedures}

The conduct of this study following the below stated Data Gathering Procedures. For the survey questionnaire floating, the researcher administered the survey questionnaires to the participants by sending an accessible Google form link where they can freely anywhere anytime the surveys. Participants would be reminded that their participation should be voluntary. Google form link was the option because of the social distancing and other quarantine health protocols imposed in the country. Giving them an electronic option is the best to observe these health procedures. The respondents automatically see if their answers are counted as they submit their forms. The second sources include the various analyses and articles derived from literature, books, journals, laws, previous and recent studies, scholarly writings, academic reports, and records from various foreign and local sources. All these were sorted and filtered and were subjected to comparison to the present study to find out if any gaps can lead to a better understanding of the topic.

\subsection{Data Analysis}

For the assessment of the demographic profile of the respondents, the gathered data were treated using the following tools: Percentage and Frequency to determine the data gathered in the demographic profile of respondents, and the evaluation on the factors affecting the customer satisfaction of customers towards the services of selected traditional authentic restaurants in Ilocos Sur, Frequency Counting, Percentage Calculation, and Ranking were used. For the assessment on the level of customer satisfaction of the customers towards the services of selected restaurants in Ilocos Sur in terms of Tangibility, Reliability, Responsiveness, Assurance, and Empathy, the weighted mean was interpreted by a 4-point Likert Scale was used.

\subsection{Ethical Consideration}

To observe the confidential nature of the survey no particular names were mentioned in the study. The identities of the respondents were not revealed and only information and results based on the data gathered are present. The research participants were not subjected to harm in any way of the results or findings of the study. This study considered the respect and dignity of research to be prioritized and full consent was obtained from the participant before the study. Lastly, the protection of the privacy of research was ensured.

\section{Results and discussion}

\section{Table 1}

Profile of the respondents

\begin{tabular}{|c|c|c|}
\hline Sex & Frequency & Percentage \\
\hline Male & 186 & 47.00 \\
\hline Female & 209 & 53.00 \\
\hline \multicolumn{3}{|l|}{ Age } \\
\hline$<21$ years old & 85 & 21.52 \\
\hline $21-25$ years old & 118 & 29.87 \\
\hline 36 - 50 years old & 145 & 36.71 \\
\hline 51 - 65 years old & 47 & 11.90 \\
\hline \multicolumn{3}{|l|}{65 years old and above } \\
\hline \multicolumn{3}{|c|}{ Educational Attainment } \\
\hline High School Graduate & 40 & 10.13 \\
\hline College Graduate & 210 & 53.16 \\
\hline Master's Degree & 110 & 27.85 \\
\hline Doctorate & 35 & 8.86 \\
\hline \multicolumn{3}{|c|}{ Monthly Income } \\
\hline$<4,000$ & 96 & 24.30 \\
\hline $4,001-8,000$ & 41 & 10.38 \\
\hline $8,001-12,000$ & 58 & 14.68 \\
\hline $12,001-16,000$ & 85 & 21.52 \\
\hline more than 16,001 & 115 & 29.12 \\
\hline
\end{tabular}

100 Consortia Academia Publishing (A Partner of Tourism Educators and Movers of the Philippines) 
Table 1 shows the profile of the respondents in this study. There are a total of 395 respondents. In terms of sex, the majority are female with 209 or 53 percent, while males are 186 or 47 percent. It can be inferred that female costumer is more likely to dine in authentic restaurants than male customers. In terms of age, the majority are between 36 to 50 or 36.71 percent. From the results above, it can be inferred those middle-aged adults are more likely to dine in authentic restaurants, followed by young adults, and least are old adults. For educational attainment, most of the respondents were college graduates with a total of 210 or 53.16 percent. Most customers that we're more likely to dine in authentic restaurants are College Graduates. For monthly income, most of the respondents have an income of more than 16,001 with a total of 115 or 29.12 percent.

According to the results of the study, many of the participants are women who choose to dine at ethnic authentic restaurants in Ilocos Sur. According to the survey's findings, most participants are women who choose to dine at ethnic authentic restaurants in Ilocos Sur. This suggests that when female customers dine in, they are happier than male customers, and they are more likely to be of a certain age. As shown by the findings, patron satisfaction in restaurants is based on both their expectations and their experience. The profile variable represented all the variables in this study that have an effect. The interrelationships between the variables were discovered in the variable comparison.

Table 2

Assessment in service quality in terms of tangible

\begin{tabular}{|c|c|c|c|}
\hline Tangible & WM & VI & Rank \\
\hline $\begin{array}{l}\text { (1) When you enter a restaurant, you feel the cool temperature, good lighting atmosphere, and nice } \\
\text { scent with soothing music that makes you comfortable to dine. }\end{array}$ & 3.72 & Agree & 3 \\
\hline $\begin{array}{l}\text { (2) When you enter a restaurant, you find that the location is nice with a perfect ambiance of the } \\
\text { restaurant's décor and aesthetics. }\end{array}$ & 3.75 & Agree & 1 \\
\hline (3) Employees are well-dressed and appear neat. & 3.74 & Agree & 2 \\
\hline $\begin{array}{l}\text { (4) You experienced good facilities (Such as nice crockery and cutlery settings, nice table setting, } \\
\text { full condiments, etc.) and hygiene of the restaurant. }\end{array}$ & 3.65 & Agree & 5 \\
\hline (5) There is clarity of the menu and offer good food quality in the restaurant. & 3.71 & Agree & 4 \\
\hline Composite Mean & 3.72 & Agree & \\
\hline
\end{tabular}

Table 2 shows the assessment in service quality in terms of tangible with a composite mean of 3.72 verbally interpreted as agree. The topmost indicators revealed that as the customer entered the restaurant, they find the location perfect view and ambiance as it fits with the restaurant's décor and aesthetics with a weighted mean of 3.75; followed by the restaurant's employee with a neat-looking dress and appearance with a weighted mean of 3.74; the third is the restaurant's cool temperature, pleasant lighting, atmosphere, and scent with a weighted mean of 3.72. The respondents found the restaurant's location to be very appealing, with perfect décor, a pleasant environment, and an ambiance in which they could eat and relax simultaneously. They also noticed that the restaurant's staff were well-dressed, which contributed to the restaurant's ideal environment. Based on the findings, an ideal environment has a substantial impact on patron satisfaction. According to previous studies by Omar et al. (2015), one of the essential elements that contribute to patron satisfaction is position layout.

The fourth indicator revealed that the restaurant has a clear menu and offers an excellent quality of food with a weighted mean of 3.71. And lastly, the restaurants have good facilities such as utensils, table settings, and have proper hygiene with a weighted mean of 3.65. The respondents also observed the restaurant foods are very pleasing with healthy food quality as well as their quality facilities. These factors were all agreed upon by the respondents. According to the results, a pleasant atmosphere has a major effect on customer satisfaction. Place layout is one of the essential elements that contribute to patron satisfaction. A pleasant atmosphere has a major effect on customer satisfaction. As one of the essential elements that contribute to patron satisfaction is place layout (Omar et al., 2015). Restaurants with decent lighting will entice customers. Restaurants use a variety of strategies to improve patrons' dining experiences, including lighting. According to Ciani (2015), lighting plays a key role in a patron's enthralling experience because it provides the perfect ambiance for the restaurant owner and designer. This setting helps guests to relax and unwind. 


\section{Table 3}

Assessment in service quality in terms of reliability

\begin{tabular}{|c|c|c|c|}
\hline Reliability & WM & VI & Rank \\
\hline (1) The restaurant performs its promised service to you as fast as possible. & 3.83 & Agree & 1 \\
\hline $\begin{array}{l}\text { (2) In a restaurant, employees behave good manners as they warmly welcome and provide } \\
\text { you with a table promptly. }\end{array}$ & 3.66 & Agree & 4 \\
\hline $\begin{array}{l}\text { (3) The employees are ready to help you when you have a problem and are reassuring if } \\
\text { something went wrong. }\end{array}$ & 3.68 & Agree & 2 \\
\hline $\begin{array}{l}\text { (4) You recognized that employees are knowledgeable by providing you information about } \\
\text { the menu items and can make suggestions for you. }\end{array}$ & 3.67 & Agree & 3 \\
\hline (5) The restaurant provides its service correctly in time. & 3.61 & Agree & 5 \\
\hline Composite Mean & 3.69 & Agree & \\
\hline
\end{tabular}
Disagree

Table 3 shows the assessment in service quality in terms of reliability with a composite mean of 3.69 verbally interpreted as agree. The topmost indicators revealed that the restaurants have fast and reliable service with a weighted mean of 3.83 ; followed by the restaurant's employees who were ready and eager to help customers with their problems with a weighted mean of 3.68; the third is the restaurant's employees were knowledgeable about their menu and offers a costumer a suggestion with assurance (3.67). The respondents observed the restaurant's fast and quality services with their well-equipped, reliable, and knowledgeable employees. The study's findings are linked to Khin's (2020) study on the evaluation of Service Quality in terms of efficiency that a restaurant provides service to customers as quickly as possible. This means that the quick service offered by an authentic restaurant's employees satisfies patrons in terms of quality service reliability. This is the case with those who have had the opportunity to dine in.

With a weighted mean of 3.66, the fourth measure showed that restaurant workers have good manners and are warm to any customer as they welcome and provide tables and any other needs of a customer. Finally, with a weighted mean of 3.61, the restaurant's service was still on time. The restaurant workers were also hospitable and served with proper conduct, according to the respondents. This also means that customers would appreciate the fact that the workers were able to provide them with accurate and timely service while they dined in.

Restaurants must maintain a high degree of consumer satisfaction in the food industry, which can be accomplished by excellent customer service. The success of a restaurant company is often in the hands of restaurant managers since it depends on their superiority in managing people's work habits. Good customer service generates delighted customers by creating interactions that meet their needs while poor customer service leads to confusion and concerns. Good customer service entails forming strong bonds with customers, which leads to positive, long-term relationships with both the consumer and the company. Customers and restaurants are both to be benefited.

\section{Table 4}

Assessment in service quality in terms of responsiveness

\begin{tabular}{|c|c|c|c|}
\hline Responsiveness & WM & VI & Rank \\
\hline (1) The employee informs you when the service will be Performed & 3.57 & Agree & 5 \\
\hline (2) Employees pay attention to you, listen, and communicate understandably. & 3.71 & Agree & 2 \\
\hline (3) Employees in the restaurant are willing to help you promptly when you request something. & 3.71 & Agree & 1 \\
\hline (4) Employees are responsible to answer your questions complaints quickly. & 3.65 & Agree & 3 \\
\hline (5) In a restaurant, when you must wait for service, you receive an apology. & 3.59 & Agree & 4 \\
\hline Composite Mean & 3.64 & Agree & \\
\hline
\end{tabular}

Legend: 4.50-5.00- Strongly Agree; 3.50 - 4.49 - Agree; 2.50 - 3.49 - Moderately Agree; 1.50 - 2.49 -Disagree; 1.00 - 1.49 - Strongly Disagree

Table 4 shows the assessment in service quality in terms of responsiveness with a composite mean of 3.64 verbally interpreted as agree. The topmost indicators revealed that the restaurant's employees helped a customer as fast as they can especially when they request something, and they were eager to listen and communicate to a customer with a nice tune of voice and/or can be easily understood by the customers with a weighted mean of 
3.71 both; the third indicator revealed that the restaurant's employees were responsible enough and knew what to respond with a weighted mean of 3.65. Employees knew how to please their customers and promptly please customers who had complaints pleasantly and pleasingly, according to the respondents. Employees knew how to please their customers and promptly please customers who had complaints nicely and pleasingly, according to the respondents. It demonstrates that being attentive and concise in engaging with customers, as well as providing them with quick service, can satisfy them when it comes to being sensitive to quality service. This demonstrated that customers receive excellent service when employees of genuine restaurants listen to their needs. The respondents also observed the restaurant's employees knew how to treat their customers nicely as well in informing them when the service will be performed so that customers would be aware and expect if they should wait or not. The lowest average mean is 3.57 under item 11, which indicated that employees did not inform patrons when the service will not be performed on time. These respondents experienced when they dine in a restaurant when employees were not able to perform the service promptly (Htun, 2020).

\section{Table 5}

Assessment in service quality in terms of assurance

\begin{tabular}{|c|c|c|c|}
\hline Assurance & WM & VI & Rank \\
\hline (1) Employees of the restaurant deliver good services. & 3.65 & Agree & 3 \\
\hline (2) Employees are well-trained and experienced in serving (Such as food, drink, etc.). & 3.67 & Agree & 1 \\
\hline $\begin{array}{l}\text { (3) Employees make sure to inform you about the specialty in the restaurant (Such as today's } \\
\text { special, promotion, special service of the month, etc.). }\end{array}$ & 3.64 & Agree & 4 \\
\hline $\begin{array}{l}\text { (4) Employees are courteous to you that their behaviors inspired you to trust when you interact } \\
\text { with them. }\end{array}$ & 3.65 & Agree & 2 \\
\hline $\begin{array}{l}\text { (5) The employees of the restaurant are empowered to handle any of your complaints to satisfy } \\
\text { you regardless of some policies }\end{array}$ & 3.60 & Agree & 5 \\
\hline Composite Mean & 3.64 & Agree & \\
\hline
\end{tabular}

Legend: 4.50-5.00- Strongly Agree; 3.50 - 4.49 - Agree; 2.50 - 3.49 - Moderately Agree; 1.50 - 2.49 -Disagree; 1.00 - 1.49 - Strongly Disagree

Table 5 shows the assessment in service quality in terms of assurance with a composite mean of 3.64 verbally interpreted as agree. The topmost indicators revealed that the restaurant employees were well-trained and experienced in serving with a weighted mean of 3.71; followed by the restaurant's employees being courteous which made their customers trust them especially when interacting with them (3.65); the third is the restaurant's employees were able to deliver good and quality services (3.65). The restaurant workers, were well-trained and experienced, allowing them to provide good and reliable service. They also noted that they could rely on these employees because they were courteous, allowing them to communicate with coworkers with ease and respect. This demonstrated that respondents received excellent service in terms of employee success in providing services such as serving their food and beverages. It also demonstrated that workers are courteous to them by observing employees' interactions (Htun 2020).

The fourth indicator revealed that the restaurant employees knew how to inform the customer about their specialties, promotions, and any other information that a customer should know with a weighted mean of 3.64. And lastly, the restaurant's employee was empowered and knew how to respond and handle customers' complain regardless of some policies with a weighted mean of 3.60. The respondents found that restaurant employees were not good at reminding a customer about the restaurant's specialties and promotions, as well as reacting and managing a customer complaint. But, since this is the least indicator, employees should focus and enhance service to a customer. Customer satisfaction and loyalty are two of the most common targets of hospitality service businesses. Employees who have been trained and who observe regular practices are more likely to be employed.

Table 6 shows the assessment in service quality in terms of empathy with a composite mean of 3.51 verbally interpreted as agreeing. The topmost indicators revealed that the restaurant's employee knew how to deal with a costumer with care and knew how to listen to their recommendations with a weighted mean of 3.59 ; followed by the restaurant's employees gave customers special attention regarding their needs, wants, and proper services 
(3.56); the third is the restaurant's employees were able to see and understand a costumer's specific requirement (3.52). Within this, it shows that patrons experienced satisfaction as employees deal with them with care and understanding as they listen to what their patron recommendations and request. Many businesses do not devote enough time or resources to efficiently manage grievances (Homburg et al, 2017). Restaurants can solve issues, boost quality, and meet customer loyalty if they pay attention to their customers' needs and desires. Being emphatic with customers demonstrates the company's ability to provide accurate service as promised. The fourth indicator revealed that the restaurant has employees who were ready to assist and provide customer service with a weighted mean of 3.45. And lastly, the restaurants have a very convenient operating hour with a weighted mean of 3.41. The restaurant employees also provided convenience to meet and provide patron needs, as well as guaranteed time to make their service convenient, according to the respondents. This may be a reliable source of crucial business insight for the service's improvement.

\section{Table 6}

Assessment in service quality in terms of empathy

\begin{tabular}{lccc}
\hline \multicolumn{1}{c}{ Empathy } & WM & VI & Rank \\
\hline (21) Employees give you individual attention to your needs and maintain proper service. & 3.56 & Agree & 2 \\
(22) The restaurant has operating hours convenient for you and all customers. & 3.41 & Strongly Agree & 5 \\
(23) In the restaurant, employees understand your requirements. & 3.52 & Agree & 3 \\
(24) The restaurant has employees to provide you, personal service. & 3.45 & Strongly Agree & 4 \\
(25) Employees deal with all customers with care and consciously listen to the & 3.59 & Agree & 1 \\
recommendations of customers. & Composite Mean & 3.51 & Agree
\end{tabular}

Legend: 4.50-5.00- Strongly Agree; 3.50 - 4.49 - Agree; 2.50 - 3.49 - Moderately Agree; 1.50 - 2.49 -Disagree; 1.00 - 1.49 - Strongly Disagree

Table 7 shows the assessment in customer satisfaction in terms of food authenticity (3.80), food quality (3.81), service quality (3.76), Physical Environment (3.77) verbally interpreted as agreeing. The topmost indicators revealed that foods served in restaurants have an attractive displayed appearance with a weighted mean of 3.86; followed by the authentic taste of the food served with a weighted mean of 3.83. Respondents preferred food served in restaurants that had a pleasing appearance and tasted authentically prepared. The complexity of a dish's composition is revealed by good and attractive food presentation. Food served in a restaurant with a flavor that exactly matches the definition demonstrates its authenticity and is well-liked by consumers because it does not fall short of their standards. Restaurants that serve authentic and creative food draw patrons who want to share it on social media. Food that is appealing even though patrons have not tasted it yet makes food tasty and authentic without even eating it, resulting in patron satisfaction and a tourism experience that increases tourist loyalty to rural destinations (Zhang et al., 2019)

The least indicator revealed that foods served in a restaurant used authentic cooking methods with a weighted mean of 3.80. And lastly, the ingredients used were local with a weighted mean of 3.69. The respondents also noted that when preparing food in a restaurant, they used authentic cooking methods as well as locally sourced ingredients that were dependable, nutritious, and met customer expectations. Food choices, such as meal source and method of preparation, have a considerable influence. Most people were aware of healthier foods and cooking methods and attempted to use them whenever possible, particularly if they had health problems (Mills et al., 2018).

As to the Food Quality, the topmost indicators revealed that foods served in restaurants were delicious with a weighted mean of 3.93; followed by the foods authentic fragrant with a weighted mean of 3.81; then the visually appealing display of the food served with a weighted mean of 3.80. Food served in restaurants with a pleasant taste, fragrance, and a delectable appearance was favored by the respondents. The attention of the customer is drawn to tasty food. Authentic cuisine has established itself as one of the key attractions for any destination. Only authentic dishes, according to Kalenjuk et al. (2015), can satisfy travelers' curiosity; their research could be useful. One of the most critical aspects of customer loyalty is food quality. Another way to ensure consumer satisfaction is to taste food. Food that is cooked in a tasty, pleasing, and nutritious manner has a 
positive effect on customers. Local cuisine reflects a place's history and culture. Food tourism relies heavily on the uniqueness of local cuisine, as food can depict regional dishes and specialties that can entice people to visit.

Food is an important cultural component that is linked to the sense of authenticity.

Table 7

Assessment in Customer Satisfaction in terms of Food Authenticity

\begin{tabular}{|c|c|c|c|c|}
\hline \multicolumn{2}{|l|}{ Food Authenticity } & \multirow{2}{*}{$\begin{array}{l}\text { WM } \\
3.69\end{array}$} & \multirow{2}{*}{$\begin{array}{c}\text { VI } \\
\text { Agree }\end{array}$} & \multirow{2}{*}{$\frac{\text { Rank }}{4}$} \\
\hline (1) Food ingredients are local. & & & & \\
\hline (2) Use authentic cooking methods. & & 3.8 & Agree & 3 \\
\hline (3) Appearance display is attractive. & & 3.86 & Agree & 1 \\
\hline (4) Food has an authentic taste. & & 3.83 & Agree & 2 \\
\hline & Composite Mean & 3.8 & Agree & \\
\hline \multicolumn{2}{|l|}{ Food Quality } & WM & VI & Rank \\
\hline (1) Food is delicious. & & 3.93 & Agree & 1 \\
\hline (2) Food is nutritious and helps health. & & 3.77 & Agree & 4 \\
\hline (3) Food smell is attractive. & & 3.81 & Agree & 2 \\
\hline (4) Food display is visually appealing. & & 3.8 & Agree & 3 \\
\hline (5) Food is fresh. & & 3.74 & Agree & 5 \\
\hline & Composite Mean & 3.81 & Agree & \\
\hline \multicolumn{2}{|l|}{ Service Quality } & WM & VI & Rank \\
\hline \multirow{6}{*}{$\begin{array}{l}\text { (1) Comfortable and tidy service are observed. } \\
\text { (2) Waiters wear proper and clean suits. } \\
\text { (3) Waiters respond to my needs immediately. } \\
\text { (4) They provide numerous services to meet the needs of Customers. } \\
\text { (5) Service is fast and efficient. }\end{array}$} & & 3.79 & Agree & 2 \\
\hline & & 3.82 & Agree & 1 \\
\hline & & 3.75 & Agree & 3 \\
\hline & & 3.74 & Agree & 4 \\
\hline & & 3.7 & Agree & 5 \\
\hline & Composite Mean & 3.76 & Agree & \\
\hline \multicolumn{2}{|l|}{ Physical Environment } & WM & VI & Rank \\
\hline \multirow{6}{*}{$\begin{array}{l}\text { (1) Layout and facilities are beautiful and interesting. } \\
\text { (2) There are Comfortable and clean tableware, tables, and chairs. } \\
\text { (3) There is Convenient transportation and adequate parking. } \\
\text { (4) Lighting is appropriate and natural. } \\
\text { (5) Indoor temperature is comfortable. }\end{array}$} & & 3.75 & Agree & 5 \\
\hline & & 3.8 & Agree & 1 \\
\hline & & 3.76 & Agree & 3 \\
\hline & & 3.78 & Agree & 2 \\
\hline & & 3.76 & Agree & 4 \\
\hline & Composite Mean & 3.77 & Agree & \\
\hline
\end{tabular}

Legend: 4.50-5.00- Strongly Agree; 3.50 - 4.49 - Agree; 2.50 - 3.49 - Moderately Agree; 1.50 - 2.49 -Disagree; 1.00 - 1.49 - Strongly Disagree

The least indicator revealed that foods served in a restaurant were nutritious and healthy with a weighted mean of 3.77. And lastly, the food was also fresh with a weighted mean of 3.74. The respondents also observed that foods must be nutritious and healthy as well. Fresh served foods were more likely to contain more nutrients than those that were not. They also define the quality of food being served. Positive food experiences are visual, and part of that is being able to consider food in its current state. Every person requires proper nutrients, so a restaurant needs to ensure that the food it serves is fresh and properly prepared before it is served. If this is done properly, patrons will be pleased and receive nutrients from what they have obtained. Customers' questions about nutritious food influence their preferences and restaurant selection. The taste, juiciness, crispness, and fresh posture of the food are used to determine freshness. Customer satisfaction is improved by high-quality food. Taste, appearance, temperature, freshness, nutrition, and menu variety all contribute to food quality. Customers' decisions to return to a restaurant are influenced by the nature of the food. (Rajput \& Gahfoor, 2020).

The topmost indicators for service quality revealed that waiters who served wears a proper and clean suit with a weighted mean of 3.82; followed by the comfortable and tidy service brought by the employees with a weighted mean of 3.79; then the quick response of waiters to costumers needs with a weighted mean of 3.75 . The waiters who served them were elegantly dressed and dressed in a proper suit, according to the respondents. They had a friendly demeanor and provided prompt service. Waiters are also diligent in their service, responding as quickly as possible to the needs of their customers. Customer service would benefit from proper management. If any staffs are not well-trained in their jobs, such as welcoming customers and properly taking orders, the restaurant will not fulfill customer expectations, and customers will flock to the restaurant if the food is not delivered on time. 
The least indicator for service quality revealed that restaurants employees provided different services for their customers' needs with a weighted mean of 3.74. And lastly, the restaurant's service was fast and very efficient with a weighted mean of 3.70. Restaurants have various methods and services in responding to the needs of each customer, so the respondents observed how quick, reliable, and effective their service was. In the food industry, a company needs to capitalize on its customers' loyalty, which can be accomplished by superior customer service. Consumer service provides experiences that are tailored to the needs of the customer. It results in delighted customers. Poor customer service leads to confusion and concerns. It will result in a loss of revenue because customers would turn to a competitor. Good customer service entails forming strong bonds with clients, which can lead to positive and long-term relationships. It benefits both the consumer and the company. Customers profit when the company provides a service that satisfies their requirements (Kanyan et al., 2016).

The topmost indicators for the physical environment revealed that restaurants have comfortable and clean tableware, tables, and chairs (3.80); followed by the restaurant's appropriate and natural lighting (3.78); then the restaurant's convenient transportation and adequate parking for customers (3.76). The restaurants have a safe, appropriate, and adequate setting, according to the respondents. Restaurants kept their surroundings tidy, including tables, chairs, and utensils, among other things. They also have adequate lighting for the entire restaurant, making it more comfortable for customers. Customers are also provided with ample parking space by restaurants, which eliminates the hassle of searching for a parking spot. Consumer behavior is determined by the ability to predict and explain human behavior. Consumer needs vary and arise regularly, along with a variety of perspectives. The consumer's attitude toward the service provider is shaped based on the service experience. This attitude may be a consistent disdain or appreciation of the service (Rajput \& Gahfoor, 2020).

The least indicator for physical environment revealed that restaurants have a comfortable indoor temperature (3.76). restaurants have a beautiful and interesting layout and facilities (3.75). The respondents also noted the restaurants' pleasant temperature and layout, down to the tiniest specifics like utensils, designs, and other elements found inside the restaurant. These images depict a restaurant's ideal ambiance. Providing the ideal ambiance and environment for a restaurant would have a positive effect on customers; but, if this is not done, negative outcomes will emerge, and customers will not be retained or referred. Both outcomes would certainly be impossible to reverse eventually and should be avoided at all costs (Khin 2020).

Table 8 shows the comparison of responses in terms of service quality when grouped by profile. Since the computed $\mathrm{p}$ values are less than 0.05 level of significance, there was a substantial difference in service quality assessment in terms of observable, reliability, responsiveness, assurance, and empathy when grouped by sex. This means that when assessing service quality in terms of tangibles like reliability, responsiveness, assurance, and empathy, the results vary depending on gender. Females were found to have a higher degree of evaluation in terms of tangible, reliability, responsiveness, assurance, and empathy when it came to service quality. Since the computed $p$ values are less than 0.05 level of significance, there was a substantial difference in the assessment of service quality in terms of tangible, reliability, responsiveness, assurance, and empathy when grouped by age. This means that when evaluating service quality in terms of tangibles like reliability, responsiveness, assurance, and empathy, the results vary. Because they are all customers, this means that regardless of the age of the customer, the same level of satisfaction should be viewed in terms of service quality or provided by an employee. The level of service provided by a local food dining experience is critical to the overall tourism experience. As a result, service quality is not only a subjective definition but also a comparison discrepancy between tourist perceptions and real acceptance of service quality (Zhang et al., 2019).

When grouped according to educational attainment, it was observed that there was a significant difference in assessment in service quality in terms of tangible, reliability, responsiveness, assurance, and empathy since the computed $\mathrm{p}$ values are less than 0.05 level of significance. This means that assessment in service quality in terms of tangible, reliability, responsiveness, assurance, empathy differs when grouped according to educational attainment. It was found out that no matter what their educational attainments it still differs on their preference on assessing the quality of service. Different customers come and go to dine, and different customers have 
Customer satisfaction basis for sustainable traditional authentic ethnic restaurants in Ilocos Sur

different educational attainment, which ensures that regardless of their educational background, satisfaction in terms of service quality and food quality must be met once the customer enters the restaurant. When grouped according to monthly income, it was observed that there was a significant difference in assessment in service quality in terms of tangible, reliability, responsiveness, assurance, empathy since the computed $\mathrm{p}$ values are less than 0.05 level of significance. This means that assessment in service quality in terms of tangible, reliability, responsiveness, assurance, empathy differs when grouped according to monthly income. It was found out that no matter what the monthly income of respondents there was a significant difference in the response. Customers' income is priced at the same level as quality service. Customers are looking for something to give them value for what they are paying for; even though they have a higher monthly income or a higher annual income, they still want the same level of service, but in a unique way. Since high-paid consumers have a higher income, they have higher expectations than low-paid customers. This means that customers have different perspectives on service quality in terms of tangibles, efficiency, responsiveness, assurance, and empathy.

Table 8

Differences in assessment in service quality when grouped into profile variables

\begin{tabular}{|c|c|c|c|}
\hline Sex & F-value & p-value & Interpretation \\
\hline Tangible & 17.20 & $<0.01$ & Significant \\
\hline Reliability & 10.95 & $<0.01$ & Significant \\
\hline Responsiveness & 12.97 & $<0.01$ & Significant \\
\hline Assurance & 18.59 & $<0.01$ & Significant \\
\hline Empathy & 10.74 & $<0.01$ & Significant \\
\hline \multicolumn{4}{|l|}{ Age } \\
\hline Tangible & 8.39 & $<0.01$ & Significant \\
\hline Reliability & 7.63 & $<0.01$ & Significant \\
\hline Responsiveness & 8.00 & $<0.01$ & Significant \\
\hline Assurance & 10.25 & $<0.01$ & Significant \\
\hline Empathy & 9.73 & $<0.01$ & Significant \\
\hline \multicolumn{4}{|c|}{ Educational Attainment } \\
\hline Tangible & 12.99 & $<0.01$ & Significant \\
\hline Reliability & 8.92 & $<0.01$ & Significant \\
\hline Responsiveness & 11.59 & $<0.01$ & Significant \\
\hline Assurance & 10.67 & $<0.01$ & Significant \\
\hline Empathy & 10.16 & $<0.01$ & Significant \\
\hline \multicolumn{4}{|c|}{ Monthly Income } \\
\hline Tangible & 3.72 & 0.01 & Significant \\
\hline Reliability & 4.33 & $<0.01$ & Significant \\
\hline Responsiveness & 2.75 & 0.03 & Significant \\
\hline Assurance & 3.54 & 0.01 & Significant \\
\hline Empathy & 5.50 & $<0.01$ & Significant \\
\hline
\end{tabular}

Legend: Significant at $p$-value $<0.05$

\section{Table 9}

Differences in assessment in customer satisfaction when grouped into profile variables

\begin{tabular}{lccc}
\hline \multicolumn{1}{c}{ Sex } & F-value & p-value & Interpretation \\
\hline Food Authenticity & 5.99 & 0.02 & Significant \\
Food Quality & 7.51 & 0.01 & Significant \\
Service Quality & 9.72 & $<0.01$ & Significant \\
Physical Environment & 8.85 & $<0.01$ & Significant \\
\hline \multicolumn{1}{c}{ Age } & & & Not Significant \\
\hline Food Authenticity & 1.33 & 0.26 & Not Significant \\
Food Quality & 2.63 & 0.05 & Significant \\
Service Quality & 6.25 & $<0.01$ & Significant \\
Physical Environment & 4.87 & $<0.01$ & Not Significant \\
\hline \multicolumn{1}{c}{ Educational Attainment } & & & Significant \\
\hline Food Authenticity & 2.42 & 0.07 & Significant \\
Food Quality & 3.70 & 0.01 & Significant \\
Service Quality & 7.95 & $<0.01$ & $<0.01$ \\
Physical Environment & 6.21 & & \\
\hline
\end{tabular}




\begin{tabular}{llcc}
\hline \multicolumn{1}{c}{ Monthly Income } & & \\
\hline Food Authenticity & 1.82 & 0.12 & Not Significant \\
Food Quality & 0.65 & 0.63 & Not Significant \\
Service Quality & 2.52 & 0.04 & Significant \\
Physical Environment & 1.81 & 0.13 & Not Significant \\
\hline
\end{tabular}

Legend: Significant at p-value < 0.05; R - Rejected; FR - Fail to Reject; S - Significant; NS - Not Significant

Table 9 presents the comparison of responses in customer satisfaction when grouped according to profile. It was observed that there was a significant difference in assessment in customer satisfaction in terms of food authenticity, food quality, service quality, and the physical environment when grouped according to sex since the computed $p$ values are less than 0.05 level of significance. This means that assessment in customer satisfaction in terms of food authenticity, food quality, service quality, and physical environment differs when grouped according to sex. It was found out that females have a higher level of assessment in customer satisfaction in terms of food authenticity, food quality, service quality, and physical environment. Customers of both sexes have different opinions or beliefs about food validity, food quality, service quality, and the physical climate. Since it is their understanding, it is essential to comprehend whatever the customer's viewpoints are. The food industry has a lot of challenges, competitions in taking part in the trends to make customers satisfied. For the authenticity of the food, restaurant management should continue to engage in creative practices in the culinary phase, as well as in the restaurant's atmosphere, operation, and climate. Attitudes in the restaurant industry can have a significant impact on the progress of innovation and long-term relevant practices to fulfill consumer expectations. Local food interactions can contribute to sustainable growth, preserve regional identities, and promote agricultural diversification, according to various researchers (Chou et al., 2016). When grouped according to age, it was observed that there is no significant difference on assessment in customer satisfaction in terms of food authenticity and food quality since the computed $p$ values are greater than and equal to 0.05 level of significance. This means that assessment in customer satisfaction in terms of food authenticity and food quality does not differ when grouped according to age. It was found out that no matter what age bracket a customer belongs to, they have the same level of customer satisfaction in terms of food authenticity and food quality. In addition, it was also observed that there was a significant difference in customer satisfaction in terms of service quality and the physical environment when grouped according to age since the computed p values are less than 0.05 level of significance. No matter the age of the customers when it comes to the food, they have the same preference when it comes to food authenticity and quality. Customers buy and pay for their food in return they wanted satisfaction with what they eat whatever their age is. No human is not eating food for this is the basic need for us to live. In the restaurant industry, Ryu et al. (2012) emphasized the value of food quality as a measure of customer satisfaction. As a result of their research, they identified five dimensions of food quality: the food is new, the food is tasty, the food is healthy, the menu items are diverse, and the food smells appealing. He said that food quality has both positive and negative effects.

Since the computed $\mathrm{p}$ values were greater than 0.05 levels of significance, there was no substantial difference in consumer satisfaction in terms of food authenticity when groups were based on educational attainment. This suggests that while customers are categorized according to educational achievement, customer satisfaction in terms of food authenticity does not vary. It was discovered that customers of all educational levels have the same degree of customer loyalty when it comes to food authenticity. Furthermore, since the computed $\mathrm{p}$ values are less than 0.05 levels of significance, it was discovered that there is a substantial difference in customer satisfaction in terms of food quality, service quality, and the physical environment when grouped by educational attainment. This assumes that customer satisfaction is measured in terms of food quality, service quality, and the physical environment. The overall result in this assessment showed that the service quality and food quality have a positive influence on customer satisfaction. However, customer satisfaction is the secret ingredient that drives every successful restaurant. It determines how products or services are provided by a restaurant to meet its customer's expectations. Customers are becoming more conscious of fast-food restaurant service, food quality, and physical environment quality. In cases where one elusive experienced restaurant must draw patrons while still retaining current patrons, patrons change frequently. There is a trend in other countries to eat out in a restaurant with relatives, friends, and coworkers. 
When grouped according to monthly income, it was observed that there was no significant difference on assessment in customer satisfaction in terms of food authenticity, food quality, and physical environment since the computed $\mathrm{p}$ values are greater than 0.05 level of significance. This means that assessment in customer satisfaction in terms of food authenticity, food quality, and physical environment does not differ when grouped according to monthly income. It was found out that no matter what the customer's monthly income was, they have the same level of customer satisfaction in terms of food authenticity, food quality, and physical environment. In addition, it was also observed that there was a significant difference in customer satisfaction in terms of service quality when grouped according to monthly income since the computed $\mathrm{p}$ values are less than 0.05 level of significance. This means that assessment in customer satisfaction in terms of service quality differs when grouped according to monthly income.

The disparity between males and females is their monthly salary or income, according to the findings of this study. Customers have the same degree of customer loyalty in terms of food authenticity, food quality, and physical environment regardless of their monthly income. Customers have the final say in which restaurants are the best and most affordable. Customers go to restaurants to unwind and enjoy what the restaurant must deliver, and this would also fall into a good ambiance that a customer requires, because the ambiance must support the service and food that the restaurant provides to its customers. In the restaurant industry, food quality is extremely important. What is the reason for this? Since it is for this reason that customers purchase, it is a matter of not only pleasing the patrons' taste buds but also exceeding their expectations. The quality of the food is critical in meeting the needs of patrons, and it is also important to meet their expectations. Food quality influences customer loyalty: customers often rate service and restaurants based on the food quality they receive.

\section{Table 10}

Proposed action plan for customer satisfaction basis for sustainable traditional ethnic authentic restaurants

\begin{tabular}{|c|c|c|}
\hline Key Result Areas/ Objectives & "Activity/Strategies & Expected Outcome \\
\hline $\begin{array}{l}\text { To improve cleanliness and orderliness } \\
\text { of the restaurant's facilities or in all } \\
\text { areas of the setting (such as nice } \\
\text { crockery and cutlery settings, nice table } \\
\text { settings, full condiments, and hygiene } \\
\text { of the restaurants) }\end{array}$ & $\begin{array}{l}\text { Monitoring, Assessing, and Evaluating if the } \\
\text { staff is doing their task; Provide a restaurant } \\
\text { cleanliness checklist card in maintaining the } \\
\text { different areas especially those that need to } \\
\text { be clean all the time. Scheduling and } \\
\text { familiarizing standard procedures in }\end{array}$ & $\begin{array}{l}\text { The staff of the restaurants will } \\
\text { maintain the cleanliness of the } \\
\text { restaurant facilities or in all aspects } \\
\text { or areas of the restaurant setting } \\
\text { (back and front of the house). The } \\
\text { staff will familiarize standard }\end{array}$ \\
\hline $\begin{array}{l}\text { To improve employees' proper work } \\
\text { etiquette in conducting service to } \\
\text { authentic restaurants from welcoming, } \\
\text { taking orders, and serving food to } \\
\text { customers. }\end{array}$ & $\begin{array}{l}\text { maintaining cleanliness and orderliness. } \\
\text { Review the service delivery system and } \\
\text { incorporating training and development in a } \\
\text { restaurant to deliver high-quality service and } \\
\text { to meet the needs of customers more } \\
\text { effectively on time, and in a friendly way or } \\
\text { other words service blueprint. A good code } \\
\text { of conduct can be written and posted on } \\
\text { notice boards and in staff areas to promote } \\
\text { good ethical behavior from staff. }\end{array}$ & $\begin{array}{l}\text { procedures in order. } \\
\text { The staff will deliver high-quality } \\
\text { service effectively and efficiently. }\end{array}$ \\
\hline $\begin{array}{l}\text { To improve the responsiveness of the } \\
\text { employees in delivering services }\end{array}$ & $\begin{array}{l}\text { Identify the problems of every area because } \\
\text { the service takes along. }\end{array}$ & $\begin{array}{l}\text { The Management sets standard } \\
\text { delivery of service like timeliness of } \\
\text { delivery. }\end{array}$ \\
\hline $\begin{array}{l}\text { To improve the employees in handling } \\
\text { complaints and train employees to } \\
\text { become knowledgeable in informing } \\
\text { the specialties of the house }\end{array}$ & $\begin{array}{l}\text { Provide monthly reviews based on the } \\
\text { encountered problems to produce a solution. }\end{array}$ & $\begin{array}{l}\text { Employees are highly trained and } \\
\text { always ready to handle problems that } \\
\text { they might encounter }\end{array}$ \\
\hline $\begin{array}{l}\text { To provide service beyond the } \\
\text { customer's expectation }\end{array}$ & $\begin{array}{l}\text { Evaluate what is the peak hours so that } \\
\text { management will identify if there is a need } \\
\text { for workforce }\end{array}$ & $\begin{array}{l}\text { Staff will provide faster service and } \\
\text { have enough time before the } \\
\text { customers come. }\end{array}$ \\
\hline $\begin{array}{l}\text { To promote and develop locally } \\
\text { produced ingredients in Ilocos Sur and } \\
\text { to develop more authentic dishes; To } \\
\text { encourage residents to produce local } \\
\text { products in Ilocos Sur and to represents } \\
\text { the lifestyle and culture of the Ilocos } \\
\text { Sur. }\end{array}$ & $\begin{array}{l}\text { Source out raw ingredients from locals; } \\
\text { Support Agri-tourism } \\
\text { Residents and tourists are engaged in a } \\
\text { program or workshop that demonstrates how } \\
\text { authentic dishes are prepared (like in } \\
\text { Pinakbet farm wherein tourists are allowed to } \\
\text { peak vegetables). }\end{array}$ & $\begin{array}{l}\text { Authentic restaurants in Ilocos Sur } \\
\text { will produce and improve } \\
\text { high-quality authentic dishes wherein } \\
\text { ingredients are locally available, and } \\
\text { this will establish its name to market, } \\
\text { and it will also support crops. } \\
\text { Authentic restaurants are preserved, }\end{array}$ \\
\hline
\end{tabular}




\begin{tabular}{lll}
\hline $\begin{array}{l}\text { To deliver nutritious and fresh foods to } \\
\text { customers }\end{array}$ & $\begin{array}{l}\text { Proper menu planning; Always serve hot } \\
\text { foods hot and cold foods cold; Always check } \\
\text { quality control of food before serving. }\end{array}$ & $\begin{array}{l}\text { improved, and shared. } \\
\text { complete meal which is nutritious } \\
\text { and fresh. }\end{array}$ \\
\hline $\begin{array}{l}\text { To improve employees in terms of } \\
\text { providing service fast and efficient. } \\
\begin{array}{l}\text { To improve layout and facilities to } \\
\text { make authentic restaurants more } \\
\text { interesting and comfortable }\end{array}\end{array}$ & $\begin{array}{l}\text { More frequent training and seminars for the } \\
\text { development of all the staff. } \\
\text { Align the designs, layouts, and service to } \\
\text { Ilocano experience or based on the theme of } \\
\text { the restaurants }\end{array}$ & $\begin{array}{l}\text { Deliver high-quality service } \\
\text { The theme of the restaurants is } \\
\text { appropriate and will be pleasing to } \\
\text { the eyes of the customers. }\end{array}$ \\
\hline \hline
\end{tabular}

\section{Conclusion and Recommendation}

Most of the respondents are females, belonging to the age group of 36-50 years, college degree holders, and with an income of more than 16,000 . The respondents agreed that restaurants provide good service quality in terms of tangible, reliability, responsiveness, assurance, and empathy. Customers are satisfied with the food authenticity, food quality, service quality, and physical environment of the authentic ethnic restaurants. A significant difference exists in the assessment in service quality in terms of tangible, reliability, responsiveness, assurance, empathy when grouped according to the profile variables. A significant difference also exists in the assessment in customer satisfaction in terms of food authenticity, food quality, service quality, and the physical environment when grouped according to sex; There is a significant difference in assessment in customer satisfaction in terms of service quality and the physical environment when grouped according to age, there is a significant difference in assessment in customer satisfaction in terms of food quality, service quality, and the physical environment when grouped according to educational attainment; and lastly, there is a significant difference in assessment in customer satisfaction in terms of service quality when grouped according to monthly income. The researcher proposed an action plan for customer satisfaction basis on sustainable service in traditional authentic ethnic restaurants in Ilocos Sur.

The authentic restaurants in Ilocos Sur may regularly give training and supervision to their workers to develop and provide quality and standardize services to customers. Authentic restaurants may focus on empathy indicators to improve the quality of service. Authentic restaurants in Ilocos Sur may continuously improve quality of service, food authenticity or do some promotional activities to develop and attract more customers to exceed satisfaction, especially that what is new will make customers used of technology to make them post in social media to recommend/share on their social networks within this publicity is already established. Since food symbolizes tourism for tourist destinations and most travelers want to try authentic foods, the province of Ilocos Sur may enhance municipalities that can develop and innovate local cuisines to expand the business that will create more job opportunities and develop destination attractiveness for travelers and even encourages entrepreneurship, reinforces destination brand identity, and builds community pride about food authenticity. Authentic restaurants may need to have comments and suggestion pages or boxes to determine the tourist holistic view of the authenticity and quality attributes of local food, as well as tourist loyalty to tourism destinations and to let customers jot in their comments which it can be used to improve service, menu and know what customer demands or looking for this will help authentic restaurants increase the level of satisfaction of customers. The College/Institution may conduct training/seminars related to service quality to meet the satisfaction of customers and serves for authentic restaurants innovation. The Proposed action plan may be implemented by the Traditional Authentic Ethnic restaurants of Ilocos Sur for the improvement and satisfaction of their customers same with through those entrepreneurs who are planning to put up restaurants in Ilocos Sur.

\section{References}

Chou, S. F., Horng, J. S., Liu, C. H., Huang, Y. C., \& Chung, Y. C. (2016). Expert concepts of sustainable service innovation in restaurants in Taiwan. Sustainability, 8(8), 739.

Ciani, A. (2015). The charter of Todi and the strategy of education for a sustainable management and promotion 
of territory. In Leal Filho W. et al. (Eds.), Implementing campus greening initiatives. Approaches, methods and perspectives (pp. 13-25). Cham: Springer.

Homburg, C., Jozić, D., \& Kuehnl, C. (2017). Customer experience management: toward implementing an evolving marketing concept. Journal of the Academy of Marketing Science, 45(3), 377-401.

Htun, H. L., Lim, D. W., Kyaw, W. M., Loh, W. N. J., Lee, L. T., Ang, B., \& Chow, A. (2020). Responding to the COVID-19 outbreak in Singapore: staff protection and staff temperature and sickness surveillance systems. Clinical Infectious Diseases, 71(8), 1947-1952.

Kalenjuk, B., Tešanović, D., Gagić, S., Erdeji, I., \& Banjac, M. (2015). Offer of authentic food as a condition for gastronomic tourism development. The European Journal of Applied Economics, 12(2), 27-34.

Kanyan, A., Ngana, L., \& Voon, B. H. (2016). Improving the service operations of fast-food restaurants. Procedia-Social and Behavioral Sciences, 224, 190-198.

Khadka, K., \& Maharjan, S. (2017). Customer satisfaction and customer loyalty [Centria University of Applied Sciences]. Marketing for Entrepreneurs and SMEs. https://doi.org/10.4337/9781781955970.00008

Khin, M. C. C. (2020). Examining the important factors of service quality contributing to customer satisfaction within foreign franchise restaurant industry in Yangon, Myanmar.

Mills, S., White, M., Wrieden, W., Brown, H., Stead, M., \& Adams, J. (2017). Home food preparation practices, experiences and perceptions: A qualitative interview study with photo-elicitation. PloS one, 12(8), $\mathrm{e} 0182842$.

Ngoc, K. M., \& Uyen, T. T. (2015). Factors affecting guest perceived service quality, product quality, and satisfaction-A study of luxury restaurants in Ho Chi Minh City, Vietnam. Journal of Advanced Management Science, 3(4).

Omar, M. S., Ariffin, H. F., \& Ahmad, R. (2016). Service quality, customers' satisfaction and the moderating effects of gender: A study of Arabic restaurants. Procedia-Social and Behavioral Sciences, 224, 384-392.

Rajput, A., \& Gahfoor, R. Z. (2020). Satisfaction and revisit intentions at fast food restaurants. Future Business Journal, 6, 1-12.

Ryu, K., Lee, H. R., \& Kim, W. G. (2012). The influence of the quality of the physical environment, food, and service on restaurant image, customer perceived value, customer satisfaction, and behavioral intentions. International journal of contemporary hospitality management.

Tandon, U., Kiran, R., \& Sah, A. N. (2017). Customer satisfaction as mediator between website service quality and repurchase intention: An emerging economy case. Service Science, 9(2), 106-120.

Zhang, T., Chen, J., \& Hu, B. (2019). Authenticity, quality, and loyalty: Local food and sustainable tourism experience. Sustainability, 11(12), 3437. 
Sanchez, R. V., \& Apritado, J. M. M.

112 Consortia Academia Publishing (A Partner of Tourism Educators and Movers of the Philippines) 